\title{
Hormonal protocols for in vitro production of Zebu and taurine embryos
}

\author{
Carlos Antônio de Carvalho Fernandes(1), Tatimara Maria Miyauchi(2), Ana Cristina Silva de Figueiredo(1), \\ Miller Pereira Palhão(1), Fabiana Cristina Varago(1), Ester Siqueira Caixeta Nogueira ${ }^{(1)}$, Jairo Pereira Neves ${ }^{(1)}$ \\ and Tochimara Aparecida Miyauchi(2)
}

\begin{abstract}
(1)Universidade José do Rosário Vellano, Departamento de Medicina Veterinária, Laboratório de Reprodução Animal, Rodovia MG 179, Km 0 , CEP37130-000Alfenas,MG,Brazil.E-mail:carlos@biotran.com.br,tina@biotran.com.br,millerpalhao@yahoo.com.br,varagovet@hotmail.com, ecaixeta@gmail.com, jpneves@terra.com.br (2)Biotecnologia e Treinamento em Reprodução Animal, Rua Tatuin, no 447, CEP 37130-000 Alfenas, MG, Brazil. E-mail: tatimara@biotran.com.br, tochimara@hotmail.com
\end{abstract}

\begin{abstract}
The objective of this work was to evaluate the effects of hormonal synchronization protocols, associated or not with follicular development stimulation, on the recovery of oocytes and on in vitro production of Bos indicus and B. taurus embryos, in different seasons. Ultrasound-guided follicular aspirations $(\mathrm{n}=237)$ were performed without pre-treatment (G1, control group) and after follicular wave synchronization (G2), or after follicular wave synchronization and follicle growth induction (G3). Bos indicus produced more oocytes and embryos than $B$. taurus ( $18.7 \pm 0.9$ vs. $11.9 \pm 0.6$ oocytes and $4.8 \pm 0.3$ vs. $2.1 \pm 0.2$ embryos). On average, oocyte and embryo yields were higher in G3 than in G2, and both were greater than in G1, which lead to a higher conversion of oocytes to embryos in these treatments. The hot or the cold season did not affect the $B$. indicus outcomes, whereas, in B. taurus, both oocyte recovery and embryo production were higher in the cold season. Follicular wave synchronization improves ovum pick-up and in vitro production of embryos in both cattle subspecies evaluated.
\end{abstract}

Index terms: Bos indicus, Bos taurus, artificial insemination, follicle growth induction, follicular wave synchronization, FSH stimulation.

\section{Protocolos hormonais para produção in vitro de embriões de zebuínos e taurinos}

Resumo - O objetivo deste trabalho foi avaliar os efeitos de protocolos hormonais de sincronização, associados ou não com o estímulo ao desenvolvimento folicular, na recuperação de oócitos e na produção in vitro de embriões de Bos indicus e B. taurus, em diferentes estações. As aspirações foliculares guiadas por ultrassom $(\mathrm{n}=237)$ foram realizadas sem pré-tratamento $(\mathrm{G} 1$, grupo controle) e após sincronização da onda folicular (G2), ou após sincronização da onda folicular e estímulo do desenvolvimento folicular (G3). Bos indicus produziu mais oócitos e embriões que $B$. taurus ( $18,7 \pm 0,9$ vs. $11,9 \pm 0,6$ oócitos e $4,8 \pm 0,3$ vs. $2,1 \pm 0,2$ embriões). Em média, as produções de oócitos e embriões foram maiores em G3 do que em G2, e ambas foram maiores que em G1, o que levou a uma maior conversão de oócitos em embriões nesses tratamentos. A estação quente ou fria não afetou os resultados de $B$. indicus, enquanto, em $B$. taurus, tanto a recuperação de oócitos quanto a produção de embriões foram maiores na estação fria. A sincronização da onda folicular melhora a aspiração folicular e a produção in vitro de embriões, em ambas as subespécies de bovinos avaliadas.

Termos para indexação: Bos indicus, Bos taurus, inseminação artificial, indução de crescimento folicular, sincronização da onda folicular, estimulação com FSH.

\section{Introduction}

In vitro production (IVP) of embryos in Brazil has grown about $10 \%$ per year over the last decade, consolidating the country as a reference for this biotechnology. According to Viana et al. (2010), 66.6\% of all in vitro bovine embryos are produced in Brazil. The author observed that over $70 \%$ of the embryos produced in 2009 were from beef breeds, with Zebu (Bos indicus) genetics.

The manipulation of follicular dynamics to synchronize the onset of a wave of follicular development and to determine the status of the donor at the time of ovum pick-up (OPU) can be used to improve the number of oocytes and the repeatability of results (Binelli et al., 2006). The synchronization 
of the follicular wave emergence aims to remove the suppressive effect of the dominant follicle and, therefore, to improve oocyte developmental potential in a given moment. According to Viana \& Bols (2005), the establishment of follicular dominance is the main factor that affects the quality of the oocytes in the pool of developing follicles. Viana et al. (2003) found that dry cows undergoing OPU at the beginning of a follicular wave produced more and better quality oocytes.

The use of estradiol (E2) analogues to synchronize the follicular wave is based on its suppressive effect on follicular growth (Miyauchi, 2010). The mechanism for this suppression involves the inhibition of the follicle-stimulating hormone (FSH) release. Therefore, the synchronization of a follicular wave with estradiol benzoate can improve the number and quality of recovered oocytes.

In taurine donors, the reduced production of oocytes is mainly due to two situations: a lower number of follicles emerging per follicular wave, and a premature atresia in follicles smaller than the diameter in which they can be identified by ultrasound and aspirated (Rubin, 2006). Some studies show that ovarian pre-stimulation with FSH is a way to increase the number and diameter of aspirated follicles and the quality of retrieved oocytes (Viana et al., 2003; Ramos et al., 2006; Miyauchi, 2010). The effects of FSH stimulation in taurine donors could be even better, because of the condition of early follicular atresia in these females. However, the results of FSH stimulation in B. taurus are contradictory (Goodhand et al., 1999; Sirard et al., 1999; De Roover et al., 2005). This variation in results may be due to differences in the adopted protocols, as the FSH was not always used in animals in the same state of follicular development.

The objective of this work was to evaluate the effects of hormonal synchronization protocols, associated or not with follicular development stimulation, on the recovery of oocytes and on in vitro production of $B$. indicus and B. taurus embryos, in different seasons.

\section{Materials and Methods}

OPU procedures $(n=237)$ were carried out in farms located in the southern region of the state of Minas Gerais, Brazil, in donors of the subspecies B. taurus (Holstein, Jersey, Simmental, and Angus) and B. indicus (Nellore, Gir, Guzera, and Brahman), for a period of 12 months. The females were housed under semi-confinement and supplemented with concentrate feeds composed mainly of corn and soybean, and minerals were available ad libitum. In order to characterize seasonal variation, the months of November to April were considered as the hot season, and those from May to October as the cold season. The animals were placed into three treatment groups: group 1, control without any treatment; group 2, synchronization of follicular wave with $2 \mathrm{mg}$ of estradiol benzoate, five days before OPU; and group 3, synchronized wave and induced follicular growth using $2 \mathrm{mg}$ of estradiol benzoate, five days before OPU, plus 75 UI of FSH twice (12/12 hours), one day before OPU. The OPU procedures were performed by the same technician, using the Mindray DP-2200 ultrasound device (Mindray, Shenzhen, China), equipped with a 7.5 MHz intravaginal microconvex transducer.

Recovered cumulus oocyte complexes were transferred to $60 \times 15 \mathrm{~mm}$ culture dishes containing DPBS medium, where they were counted and sorted based on their morphological appearance, using a stereoscopic microscope with $40 \mathrm{X}$ magnification, as described by Viana et al. (2004). After classification, the oocytes were transferred to $1.2 \mathrm{~mL}$ cryotubes containing TCM-199 and were transported in a portable incubator, model INC2040-R1 (Bioceler, Belo Horizonte, $\mathrm{MG}, \mathrm{Brazil}$ ), at $37.5^{\circ} \mathrm{C}$, to the IVP laboratory. The maturation and culture conditions were $38.5^{\circ} \mathrm{C}, 5 \% \mathrm{CO}_{2}$, and saturated humidity. The semen used for the in vitro fertilization was processed in a Percoll gradient. After in vitro fertilization, presumptive zygotes were transferred to in vitro culture dishes, where they remained for seven days. After this fertilization period, embryos were evaluated and classified according to their quality and stage of development, using the classification recommended by the International Embryo Transfer Society (IETS). Only embryos classified as grade 1 were transferred.

The number of total and viable oocytes recovered and the number of embryos produced according to seasons, genetic groups (subspecies), and breeds were tested for normality and, if normally distributed, they were subjected to the analysis of variance. Differences between treatment means were evaluated by the Duncan test, at 5\% probability. Data not normally distributed were evaluated with the Wilcoxon test. The 
conversion rate of oocytes to embryos was compared by the chi-square test, at $5 \%$ probability.

\section{Results and Discussion}

There was no effect of breed subspecies (B. taurus or $B$. indicus) on the studied variables. Zebu donors produced more total and viable oocytes and embryos than B. taurus donors (Table 1). This result was expected and previously reported (Morotti et al., 2014). The higher number of oocytes recovered from $B$. indicus breeds is probably a consequence of the higher number of follicles emerging in each follicular wave, when compared to B. taurus (Silva-Santos et al., 2013).

The mean viable oocytes obtained by OPU were higher than in some studies (Viana \& Bols, 2005) but lower than in others (Morotti et al., 2014). Significant variations in follicular recruitment and in the number of recovered oocytes were reported among breeds and also between individuals within breeds (De Roover et al., 2005). It is not totally clear why B. taurus has fewer follicles during the follicular waves. One hypothesis is that the higher number of oocytes in $B$. indicus comes from a larger population of preantral follicles, compared with B. taurus (Rubin, 2006). However, in recent studies, no difference was found in the ovarian reserve between the subspecies (Silva-Santos et al., 2013). Another theory is that the period of germ cell multiplication occurs differently for them or later at the end of cell multiplication in B. indicus females (Rubin, 2006), which remains to be elucidated. Indeed, it is somewhat problematic to compare results from follicular aspirations among studies performed under different circumstances, by different technicians, as there are many variables that affect the results.

The conversion rate (oocytes to embryos) did not differ between groups, and, therefore, the largest oocyte

Table 1. Influence of the cattle breed subspecies Bos taurus and $B$. indicus on oocyte recovery and in vitro embryo production $^{(1)}$.

\begin{tabular}{lcccccc}
\hline Subspecies & \multirow{2}{*}{$\mathrm{N}$} & \multicolumn{2}{c}{ Oocytes } & & \multicolumn{2}{c}{ Embryos } \\
\cline { 3 - 4 } \cline { 6 - 7 } & & Total & Viable & & Total & CR (\%) \\
\hline Bos taurus & 121 & $11.9 \pm 0.6 \mathrm{a}$ & $8.8 \pm 0.5 \mathrm{a}$ & & $2.1 \pm 0.2 \mathrm{a}$ & $23.9 \pm 1.2 \mathrm{a}$ \\
Bos indicus & 116 & $18.7 \pm 0.9 \mathrm{~b}$ & $15.2 \pm 0.7 \mathrm{~b}$ & & $4.8 \pm 0.3 \mathrm{~b}$ & $31.6 \pm 1.1 \mathrm{a}$ \\
\hline Total & 237 & $14.9 \pm 0.6$ & $12.1 \pm 0.5$ & & $3.3 \pm 0.2$ & $27.7 \pm 1.2$ \\
\hline
\end{tabular}

${ }^{(1)}$ Means \pm standard-deviation followed by equal letters do not differ by Duncan's test, at $5 \%$ probability. CR, conversion rate. production in Zebu donors resulted in more embryos produced. Wohlres-Viana et al. (2011) verified that, in addition to differences in the ovarian physiology, cattle breeds with different genetic background also differ as to their potential for in vitro production of embryos; some of these differences stem from cellular and molecular adaptations to the environment.

When donor data were analyzed altogether, regardless of the genetic origin, hormonal protocols with synchronization of wave of follicular development (G2) and with synchronization added to induced follicular growth (G3) performed better than the control group (G1), both for oocyte recovery and embryo production (Table 2 ).

The conversion rate of oocytes to embryos was similar in treatments G2 and G3, and both were higher than in the control group. This indicates that, in addition to increasing the number of oocytes, treatments increased their quality. According to Viana \& Bols (2005), synchronization of follicular development prior to OPU is beneficial not only to increase the number of follicles available for aspiration, but also to avoid the presence of atretic follicles, because the cohort of follicles will be at the beginning of a follicular wave and, therefore, it will provide better quality oocytes.

However, when data was analyzed according to the subspecies, differences were detected (Table 3). Whereas variables for $B$. taurus females did not differ between treatments, for Zebu females, they responded to the treatments. In taurine females, the onset of atresia occurs at earlier stages after emergence (Silva-Santos et al., 2013), and the use of FSH probably made a difference by encouraging the development of those follicles, which normally would not be perceived without this stimulus. In Zebu, as atresia starts later, healthy follicles developed to a diameter in which they

Table 2. Effect of follicular wave synchronization and of follicular wave synchronization plus follicle growth induction with follicle-stimulating hormone (FSH) on oocyte recovery and embryo production ${ }^{(1)}$.

\begin{tabular}{lcccccc}
\hline Treatment & $\mathrm{N}$ & \multicolumn{2}{c}{ Oocytes } & & \multicolumn{2}{c}{ Embryos } \\
\cline { 3 - 4 } \cline { 6 - 7 } & & Total & Viable & & Total & $\mathrm{CR}(\%)$ \\
\hline Control & 79 & $10.7 \pm 0.9 \mathrm{a}$ & $8.1 \pm 0.8 \mathrm{a}$ & & $1.5 \pm 0.3 \mathrm{a}$ & $14.5 \pm 1.4 \mathrm{a}$ \\
Synchronization & 77 & $14.3 \pm 0.9 \mathrm{~b}$ & $11.2 \pm 0.8 \mathrm{~b}$ & & $3.5 \pm 0.4 \mathrm{~b}$ & $26.4 \pm 1.3 \mathrm{~b}$ \\
Synchronization + FSH & 81 & $17.8 \pm 1.4 \mathrm{c}$ & $13.8 \pm 0.8 \mathrm{c}$ & & $4.6 \pm 0.6 \mathrm{c}$ & $27.5 \pm 1.8 \mathrm{~b}$ \\
\hline Total & 237 & $14.9 \pm 0.6$ & $11.6 \pm 0.5$ & & $3.3 \pm 0.2$ & $22.4 \pm 1.2$ \\
\hline
\end{tabular}

${ }^{(1)}$ Means \pm standard-deviation followed by equal letters do not differ by Duncan's test, at $5 \%$ probability. CR, conversion rate. 
could be identified and aspirated, even without the FSH stimulation.

Moreover, in taurine donors, the addition of FSH stimulation was beneficial for the IVP of embryos, when compared to simple synchronization of the follicular wave. This effect was not observed in the Zebu females. These data agree with those of Viana et al. (2003), who showed that FSH increased oocyte quality in protocols for OPU.

Gibbons et al. (1997) found that FSH promotes embryo development in vitro by synchronizing the follicular population, by inducing in vivo maturation of oocytes, and, therefore, by leading to an increased developmental competence of the oocyte before recovery.

In the present work, there was no interaction between seasons and treatments. The seasons influenced the recovery of total and viable oocytes and the production of embryos only in B. taurus donors. In periods of higher temperature, these variables decreased in B. taurus donors (Table 4), which was not observed in Zebu. The greater sensitivity to tropical climatic conditions of $B$. taurus cows and the deleterious effect of heat stress on the results of IVP of embryos were already described for different regions (Merton et al., 2003; Viana \& Bols, 2005). Camargo et al. (2007) reported that oocytes from Gir (B. indicus) donors were more competent for embryonic development in

Table 3. Effect of follicular wave synchronization and of follicular wave synchronization plus follicle growth induction with follicle-stimulating hormone (FSH) on mean oocyte recovery and embryo production in donors of different cattle genetic groups ${ }^{(1)}$.

\begin{tabular}{lcccc}
\hline Parameter & Control & Synchronized & $\begin{array}{c}\text { Synchronized } \\
\text { plus FSH }\end{array}$ & $\begin{array}{c}\text { Total } \\
\text { mean }\end{array}$ \\
\hline \multicolumn{5}{c}{ Bos taurus } \\
$\mathrm{N}$ & 44 & 35 & 42 & 121 \\
Total oocytes & $7.8 \pm 0.8 \mathrm{a}$ & $11.9 \pm 1.2 \mathrm{~b}$ & $14.3 \pm 1.3 \mathrm{~b}$ & $11.9 \pm 0.6$ \\
Viable oocytes & $5.4 \pm 0.6 \mathrm{a}$ & $8.4 \pm 0.9 \mathrm{~b}$ & $11.9 \pm 1.1 \mathrm{c}$ & $8.8 \pm 0.5$ \\
Embryos & $1.0 \pm 0.2 \mathrm{a}$ & $2.1 \pm 0.4 \mathrm{~b}$ & $2.9 \pm 0.6 \mathrm{c}$ & $2.1 \pm 0.2$ \\
$\mathrm{CR}(\%)$ & $19.5 \pm 1.9 \mathrm{a}$ & $29.6 \pm 1.9 \mathrm{~b}$ & $24.5 \pm 1.7 \mathrm{~b}$ & $23.9 \pm 1.2$ \\
\hline \multicolumn{5}{c}{ Bos indicus } \\
$\mathrm{N}$ & 35 & 42 & 39 \\
Total oocytes & $15.1 \pm 1.9 \mathrm{a}$ & $19.5 \pm 1.8 \mathrm{~b}$ & $20.4 \pm 1.9 \mathrm{~b}$ & $18.7 \pm 0.9$ \\
Viable oocytes & $12.8 \pm 1.5 \mathrm{a}$ & $14.6 \pm 1.4 \mathrm{~b}$ & $16.9 \pm 1.7 \mathrm{~b}$ & $15.2 \pm 0.7$ \\
Embryos & $3.7 \pm 0.6 \mathrm{a}$ & $5.1 \pm 0.5 \mathrm{~b}$ & $5.8 \pm 0.9 \mathrm{~b}$ & $4.8 \pm 0.5$ \\
CR (\%) & $28.9 \pm 1.8 \mathrm{a}$ & $34.9 \pm 1.5 \mathrm{~b}$ & $34.3 \pm 1.9 \mathrm{~b}$ & $31.6 \pm 1.7$ \\
\hline
\end{tabular}

${ }^{(1)}$ Means \pm standard-deviation followed by equal letters do not differ by Duncan's test, at $5 \%$ probability. CR, conversion rate.
Table 4. Season effect on the recovery of oocytes and embryo production in different cattle genetic groups ${ }^{(1)}$.

\begin{tabular}{lccc}
\hline Parameter & Hot season & Cold season & Total mean \\
\hline & \multicolumn{3}{c}{ Bos taurus } \\
$\mathrm{N}$ & 59 & 62 & 121 \\
Total oocytes & $8.7 \pm 0.6 \mathrm{a}$ & $13.1 \pm 0.7 \mathrm{~b}$ & $11.9 \pm 0.6$ \\
Viable oocytes & $7.7 \pm 0.6 \mathrm{a}$ & $11.1 \pm 0.7 \mathrm{~b}$ & $8.8 \pm 0.5$ \\
Embryos & $1.2 \pm 0.6 \mathrm{a}$ & $2.9 \pm 0.7 \mathrm{~b}$ & $2.1 \pm 0.2$ \\
$\mathrm{CR}(\%)$ & $16.8 \pm 1.6 \mathrm{a}$ & $27.1 \pm 1.2 \mathrm{~b}$ & $23.9 \pm 1.2$ \\
\hline & \multicolumn{3}{c}{ Bos indicus } \\
$\mathrm{N}$ & 53 & 63 & 116 \\
Total oocytes & $20.9 \pm 0.8 \mathrm{a}$ & $17.1 \pm 0.9 \mathrm{a}$ & $18.7 \pm 0.9$ \\
Viable oocytes & $17.2 \pm 1.3 \mathrm{a}$ & $13.3 \pm 1.2 \mathrm{a}$ & $15.2 \pm 0.7$ \\
Embryos & $4.9 \pm 0.6 \mathrm{a}$ & $4.6 \pm 0.7 \mathrm{a}$ & $4.8 \pm 0.5$ \\
CR (\%) & $32.4 \pm 1.2 \mathrm{a}$ & $30.1 \pm 1.2 \mathrm{a}$ & $31.6 \pm 1.7$ \\
\hline
\end{tabular}

(1) Means \pm standard-deviation followed by equal letters do not differ by Duncan's test, at $5 \%$ probability. CR, conversion rate.

vitro and appeared to be under less thermal stress than oocytes from Holstein donors.

In addition to the differences in the recovery of oocytes, the production of embryos was further affected by season in the taurine donors. The conversion rate in embryos of this subspecies was lower in summer than in $B$. indicus. Altogether, the lowest recovery of oocytes and the lowest conversion rate resulted in the production of less than half of the embryos produced in the cold season. Once more, the detrimental effect of season on the conversion rate was not observed in B. indicus donors. According to Al-Katanani (2002), embryonic development in females of European breeds is influenced by previous exposure of the oocyte and embryo to heat stress; during the summer period, aspirated oocytes have their capacity for development to blastocyst reduced during IVP of embryos, when compared to winter.

\section{Conclusions}

1. Follicular wave synchronization improves ovum pick-up and in vitro production (IVP) of embryos in Bos taurus and B. indicus cattle.

2. The combination of follicular wave synchronization and exogenous stimulation of follicular growth improves these results only in B. taurus donors.

3 . The hot season is associated with a reduction in IVP of embryos from B. taurus donors, regardless of the synchronization or the exogenous stimulus for follicular growth. 


\section{Acknowledgements}

To Coordenação de Aperfeiçoamento de Pessoal de Nível Superior (Capes), for scholarship granted and to Fundação de Amparo à Pesquisa do Estado de Minas Gerais (Fapemig), for financial support.

\section{References}

AL-KATANANI, Y.M.; PAULA-LOPES, F.F.; HANSEN, P.J. Effect of season and exposure to heat stress on oocyte competence in Holstein cows. Journal of Dairy Science, v.85, p.396-409, 2002. DOI: $10.3168 /$ jds.S0022-0302(02)74086-1.

BINELLI, M.; IBIAPINA, B.T.; BISINOTTO, R.S. Bases fisiológicas, farmacológicas e endócrinas dos tratamentos de sincronização do crescimento folicular e da ovulação. Acta Scientiae Veterinariae, v.34, p.1-7, 2006.

CAMARGO, L.S.A.; VIANA, J.H.M.; RAMOS, A.A.; SERAPIÃO, R.V.; SÁ, W.F. de; FERREIRA, A.M.; GUIMARÃES, M.F.M.; VALE FILHO, V.R. do. Developmental competence and expression of the Hsp 70.1 gene in oocytes obtained from Bos indicus and Bos taurus dairy cows in a tropical environment. Theriogenology, v.68, p.626-632, 2007. DOI: 10.1016/j.theriogenology.2007.03.029.

DE ROOVER, R.; GENICOT, G.; LEONARD, S.; BOLS, P.; DESSY, F. Ovum pick up and in vitro embryo production in cows superstimulated with an individually adapted superstimulation protocol. Animal Reproduction Science, v.86, p.13-25, 2005. DOI: 10.1016/j.anireprosci.2004.05.022.

GIBBONS, J.R.; WILTBANK, M.C.; GINTHER, O.J. Functional interrelationships between follicles greater than $4 \mathrm{~mm}$ and the follicle-stimulating hormone surge in heifers. Biology of Reproduction, v.57, p.1066-1073, 1997. DOI: 10.1095/ biolreprod57.5.1066.

GOODHAND, K.L.; WATT, R.G.; STAINES, M.E. In vivo oocyte recovery and in vitro embryo production from bovine donors aspirated at different frequencies or following FSH treatment. Theriogenology, v.51, p.951-961, 1999. DOI: 10.1016/ S0093-691X(99)00041-2.

MERTON, J.S.; DE ROOS, A.P.W.; MULLAART, E.; DE RUIGH, L.; KAAL, L.; VOS, P.L.A.M.; DIELEMAN, S.J. Factors affecting oocyte quality and quantity in commercial application of embryo technologies in the cattle breeding industry. Theriogenology, v.59, p.651-674, 2003. DOI: 10.1016/ S0093-691X(02)01246-3.

MIYAUCHI, T.M. Efeito da sincronização folicular e da estimulação com FSH sobre os resultados da aspiração folicular. 2010. 72p. Dissertação (Mestrado) - Universidade José do Rosário Vellano, Belo Horizonte.
MOROTTI, F.; SANCHES, B.V.; PONTES, J.H.F.; BASSO, A.C.; SIQUEIRA, E.R.; LISBOA, L.A.; SENEDA, M.M. Pregnancy rate and birth rate of calves from a large-scale IVF program using reverse-sorted semen in Bos indicus, Bos indicus-taurus, and Bos taurus cattle. Theriogenology, v.81, p.696-701, 2014. DOI: 10.1016/j.theriogenology.2013.12.002.

RAMOS, A.A.; FERREIRA, A.M.; SÁ, W.F.; CAMARGO, L.S.A.; VIANA, J.H.M.; HENRY, M.R.J.M. Protocolos de produção in vitro de embriões na raça Gir. Arquivo Brasileiro de Medicina Veterinária e Zootecnia, v.58, p.372-380, 2006. DOI: 10.1590/ S0102-09352006000300009.

RUBIN, K.C.P. Particularidades reprodutivas da raça Nelore na produção in vitro de embriões (PIVE). 2006. 46p. Dissertação (Mestrado) - Universidade Estadual de Londrina, Londrina.

SILVA-SANTOS, K.C.; MARINHO, L.S.R.; SANTOS, G.M.G.; MACHADO, F.Z.; GONZALEZ, S.M.; LISBOA, L.A.; SENEDA, M.M. Ovarian follicle reserve: emerging concepts and applications. Animal Reproduction, v.10, p.180-186, 2013.

SIRARD, M.-A.; PICARD, L.; DERY, M.; COENEN, K.; BLONDIN, P. The time interval between FSH administration and ovarian aspiration influences the development of cattle oocytes. Theriogenology, v.51, p.699-708, 1999. DOI: 10.1016/ S0093-691X(99)00019-9.

VIANA, J.H.M.; BOLS, P.E.J. Variáveis biológicas associadas a recuperação de complexos cumulus-oócito por aspiração folicular. Acta Scientiae Veterinariae, v.33, p.1-2, 2005. Suplemento.

VIANA, J.H.M.; CAMARGO, L.S. de; FERREIRA, A. de M.; SÁ, W.F. de; FERNANDES, C.A. de C.; MARQUES JUNIOR, A. de. Short intervals between ultrasonographically guided follicle aspiration improve oocyte quality but do not prevent establishment of dominant follicles in the Gir breed (Bos indicus) of cattle. Animal Reproduction Science, v.84, p.1-12, 2004. DOI: 10.1016/j.anireprosci.2003.12.002.

VIANA, J.H.M.; FERREIRA, A.M.; CAMARGO, L.S.A.; SÁ, W.F.; FERNANDES, C.A.C.; MARQUES JÚNIOR, A.P. Efeito da pré-estimulação sobre característica de oócitos após punção folicular em bovinos. Arquivo Brasileiro de Medicina Veterinária e Zootecnia, v.55, p.68-81, 2003. DOI: 10.1590/ S0102-09352003000100010.

VIANA, J.H.M.; SIQUEIRA, L.G.B.; PALHÃO, M.P.; CAMARGO, L.S. de A. Use of in vitro fertilization technique in the last decade and its effect on Brazilian embryo industry and animal production. Acta Scientiae Veterinariae, v.38, p.661-674, 2010.

WOHLRES-VIANA, S.; PEREIRA, M.M.; VIANA, J.H.M.; MACHADO, M.A.; CAMARGO, L.S. de A. Comparison of gene expression in Bos indicus and Bos taurus embryos produced in vivo or in vitro. Livestock Science, v.140, p.62-67, 2011. DOI: 10.1016/j.livsci.2011.02.008

Received on May 23, 2014 and accepted on September 30, 2014

Pesq. agropec. bras., Brasília, v.49, n.10, p.813-817, out. 2014 DOI: $10.1590 / \mathrm{S} 0100-204 \mathrm{X} 2014001000008$ 